Pak. J. Agri. Sci., Vol. 56(3), 541-548; 2019

ISSN (Print) 0552-9034, ISSN (Online) 2076-0906

DOI: $10.21162 / P A K J A S / 19.7276$

http://www.pakjas.com.pk

\title{
EXOGENOUS APPLICATION OF SALICYLIC ACID AT DIFFERENT PLANT GROWTH STAGES IMPROVES PHYSIOLOGICAL PROCESSES IN MARIGOLD (Tagetes erecta L.)
}

\author{
Syed Mohsin Abbas ${ }^{1, *}$, Rashid Ahmad ${ }^{1}$, Ejaz Ahmad Waraich' ${ }^{1}$ and Muhammad Qasim² \\ ${ }^{1}$ Department of Agronomy, University of Agriculture, Faisalabad, Pakistan; ${ }^{2}$ Institute of Horticultural Sciences, \\ University of Agriculture, Faisalabad, Pakistan. \\ *Corresponding author's email: mohsinme@live.com
}

\begin{abstract}
Marigold (Tagetes erecta L.) is a famous flowering plant in the world which has medicinal and industrial values. In Pakistan, it is an important floricultural crop and used widely as bedding plant. Pakistan is facing water shortage, which is affecting crops growth and productivity including marigold badly. Drought stress reduces plant growth, physiological and biochemical processes and flower yield in marigold. Salicylic acid (SA) is a phytohormone and its exogenous application is an effective approach to support plant during drought stress and mitigate its harmful impacts. Present study was planned to evaluate the effect of exogenous salicylic acid application on growth response and drought tolerance potential of marigold. For this purpose, a pot experiment was conducted in rain out shelter with four treatments of SA i.e., no SA application, SA foliar @ $100 \mathrm{mg} \mathrm{L}^{-1}$ application at vegetative growth, reproductive growth and at vegetative plus reproductive growth stages, under normal irrigation as well as under drought stress conditions were imposed. Drought stress was applied by skipping every alternate irrigation. The results showed that SA application at reproductive growth stage of marigold improved plant growth by improving its physiological processes during drought stress. It was concluded that exogenous application of SA, not only increased bioproductivity of marigold plants but also ameliorated the negative impacts of drought stress by enhancing drought tolerance potential in plants.

Keywords: Marigold, drought, foliar spray, salicylic acid, physiological processes
\end{abstract}

\section{INTRODUCTION}

Marigold (Tagetes erecta L.) belongs to genus Tagetes which is famous for its ornamental beauty and medicinal values. Marigold is an herbaceous annual plant with bright flowers of varying colors and sizes. China, India and Peru are leading producers of marigold in the world. In Pakistan, it is a major floricultural crop that is available in the market throughout the year. Due to its availability in various seasons, it has become a favorite bedding and container plant among the gardening community in Pakistan. Marigold is cultivated as crop to fulfill the demand of loose flowers and garlands for decoration at various ceremonies and as raw material in different industries in the country. Marigold is being used in folk medicine since ancient times. It is evident from history that this herb has been used in religious events as well as in different therapies (Khulbe, 2015). Its aromatic nature and essential oil contents make marigold more valuable for cosmetic and perfumery industry (Devika and Koilpillai, 2014). Petals of marigold contain lutein di-esters (xanthophyll) that is used for food value addition, manufacturing drugs, as natural colorant in textile dying and for manufacturing of poultry feed to get yellow egg skin and yolk naturally (Deineka et al., 2014). Its flower extract has mosquitocidal properties and can potentially be used as insecticide (Mavi, 2014). Extracts of leaves and roots of marigold have been reported to contain triterpene, thiophene, and steroids (Munhoza et al., 2014). For biological control of nematodes, marigold leaf extract is applied to nematode affected crops (Balbaa et al., 2008).

Among all abiotic stresses, drought stress affects plant growth the most and it is considered the major reason of yield loss in important crops all over the world. Shortage of irrigation water, puts stress on plant growth and reduces crop yield (Ashraf, 2010). Drought causes disturbances in photosynthetic rate as stomata are closed to avoid water loss in plants (Moussa, 2006; Mastalerczuk et al., 2017) and activities of many enzymes involved in Calvin cycle (Monakhova and Chernyadev, 2002). Water deficit is major cause of reduction in plants water contents and growth which leads to crop failure (Zhang et al., 2011). As a result of these changes some allied changes, like production of various unstable molecules of oxygen produce in mitochondria and chloroplast which are known as active/reactive oxygen species (ROS) (Arora et al., 2002). When ROS are overproduced, they cause lipid peroxidation (Zhang et al., 2011) and damage chlorophyll, protein, deoxyribonucleic acid (DNA), lipids and various important organic molecules in plant cells (Jiang and Zhang, 2001). 
Drought is serious problem for marigold as it damages its growth and leads to the plant death. Drought effects seed germination, height of seedlings, water potential and growth by reducing photosynthesis and respiration (Zhang et al., 2011). Poor flower quality, disturbance in flowering time, decrease in plant height and lower water potential in marigold are observed during drought (Burnett et al., 2006). Leaf ammonium concentration is increased, leaf chlorophyll contents are decreased and proteolysis is noticed in leaves of marigold as result of drought stress (Chyliński and Łukaszewska, 2008; Jamil et al., 2018). Under drought stress, leaves are wilted as a results of dehydration which is very common in marigold and its main reason is reduction in photosynthesis and increase in the production of ROS. Cellular membrane and leaf chlorophyll are damaged due to ROS in marigold.

In plant body, salicylic acid is produced naturally which is important for better growth and enhancing natural defense system of plants. During biotic and abiotic stresses salicylic acid exogenous application is found effective in major crop because it can repair the damage caused by these environmental hazards (Miura and Tada, 2014). Use of salicylic acid is suggested to increase drought tolerance in plants (Miura and Tada, 2014). Keeping in view the climatic prediction of upcoming drought and global warming and importance of marigold plant in ornamental and pharmacology industry, a study was planned to explore the effect of salicylic acid exogenous application during drought stress on different physiological processes and plant growth of marigold.

\section{MATERIALS AND METHODS}

Pot experiment: This experiment was performed at rain-out shelter of the department of Agronomy, University of Agriculture Faisalabad, Pakistan using a local marigold variety of marigold (Gutta/ Desigainda). Seeds were collected from a local nursery and sterilization was done by using $5 \%$ sodium hypochlorite solution for three minutes and rinsed thoroughly with distilled water. Seeds of marigold were sown in germination trays having peat moss as growing media. After 24 days, the seedlings ( 5 seedlings /pot which were later thinned to 3 seedlings /plant) were transplanted into $240 \mathrm{~mm}$ diameter pots already filled with silt, sand and leaf manure mixture with 1:1:1 ratio. To meet nutrition requirement of plants, Hoagland solution $\left(1 / 5^{\text {th }}\right.$ strength) was applied (Hoagland and Arnon, 1950). Before starting drought stress treatment, seedlings were given time to acclimatize and establish for 20 days.

Drought stress and treatments: Drought stress was applied by skipping every alternate irrigation after 20 days of seedling establishment. After that, one treatment was without salicylic acid application and in other treatments salicylic acid was foliar sprayed with $100 \mathrm{mgL}^{-1}$ concentration, at vegetative (30 days after transplanting), reproductive (when first flower bud was opened) and at both vegetative plus reproductive growth stages of marigold. The experiment was arranged in complete randomized design (CRD) with three replications. There were total 24 pots which were divided into 4 sets having salicylic acid application at different crop growth/developmental stages of marigold after imposing moisture stress. Each set had six pots (three pots with normal irrigation and three pots with drought stress). After salicylic acid application at different growth stages of marigold, data for physiological indices including fresh and dry biomass, flowering yield were collected from randomly selected plants from each pot.

Plant water relations: To evaluate leaf water potential (-MPa), a fully expanded third leaf from top of plants was harvested at mature stage. Samples were collected in the morning (06:00 - 09:00 a.m.) for measurement of water potential $(\Psi w)$ by using pressure chamber ("Scholander" type) (Model-1000, PMS instruments company, OR-USA). Osmotic potential $(-\mathrm{MPa})$ was measured from the leaf samples by which water potential was determined. For seven days, these leaves were frozen at $-20^{\circ} \mathrm{C}$ and then these leaves were thawed and crushed with a glass rod in a append of tube to extract cell sap. This cell sap was used to estimate the value of leaf osmotic potential ( $\Psi_{S}$ ) using an osmometer (Osmomat030, Germany). By subtracting the above value of osmotic potential $\left(\Psi_{s}\right)$ from water potential $\left(\Psi_{w}\right)$, turgor potential $(\mathrm{MPa})(\Psi p)$ of leaves was determined using following formula:

$$
\Psi p=\Psi w-\Psi_{S}
$$

To determine the value of relative water content (RWC) (\%), from the top of plant the third maximum expanded leaf was taken as sample. For collection of leaf samples, plastic bags were used and immediately taken to the laboratory. Digital electrical balance was used to know leaf fresh weight and then soaked these leaves in distilled water for $24 \mathrm{~h}$ in small cups made up of plastic. After that leaves were removed to obtain turgid weight with the help of weighing balance. To obtain the oven dry weight, these leaves were placed in oven at $65^{\circ} \mathrm{C}$ temperature for 74 hours. To calculate the amount of relative water contents, the method described by Cornic (1994) was followed.

$$
\mathrm{RWC}=[(\mathrm{FW}-\mathrm{DW}) /(\mathrm{TW}-\mathrm{DW})] \times 100
$$

Where, FW =Sample fresh weight, DW =Sample dry weight, TW = Sample turgid weight

Gas exchange parameters: Gas exchange parameters were determined by portable infrared gas analyzer (LCA-4 ACD) (Analytical Development, Hoddesdon, UK). For this purpose fully expanded leaf from middle of plant was selected to take

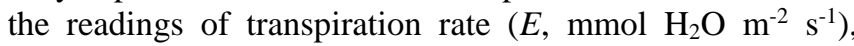
photosynthetic rate $\left(A, \mu \mathrm{mol} \quad \mathrm{CO}_{2} \quad \mathrm{~m}^{-2} \mathrm{~s}^{-1}\right)$, stomatal conductance $\left(g_{\mathrm{s}}, \mathrm{mol} \mathrm{m} \mathrm{m}^{-2} \mathrm{~s}^{-1}\right)$ and Sub-stomatal $\mathrm{CO}_{2}$ rate (internal $\mathrm{CO}_{2}$ concentration) $(\mathrm{C} i)$ during 09:00 a.m. to 11:00 a.m. At the end of each experiment, three plant per pot were harvested and dried in oven at $70^{\circ} \mathrm{C}$ till a constant weight. 
Dry matter: Dry weight was recorded using electric weighing balance. To calculate the average dry weight, added amount of dry weights of all samples and divided them by the total number of samples.

Statistical data analysis: The data collected from the experimentation was statistically analyzed by following the method of analysis of variance and Statistix-8.1(software). For calculation of differences among the treatment means, applied least significant difference (LSD) test at probability $\mathrm{P}$ $\leq 0.05$ (Steel et al., 1997).

\section{RESULTS}

The results of leaf water potential $(\Psi \mathrm{w})$ of marigold are presented in Figure 1. The data showed a significant decline in leaf $\Psi_{\mathrm{W}}$ due to drought (Table 1). In normal moisture supply, $100 \mathrm{mg} \mathrm{L}^{-1}$ salicylic acid spray at vegetative plus reproductive growth stages, produced the maximum value of $\Psi \mathrm{w}$. However, during moisture deficit environment, the greater value of $\Psi_{\mathrm{W}}$ was observed when $100 \mathrm{mg} \mathrm{L}^{-1}$ salicylic acid was sprayed at reproductive growth stage. Whereas, plants grown without salicylic acid spray (No SA), exhibited the minimum value of leaf water potential in control and drought stress conditions (Fig. 1). As shown in the data that leaf osmotic potential ( $\left.\Psi_{s}\right)$ was greatly affected by unavailability of water (Table 1). The foliar applied salicylic acid at reproductive growth stage produced the maximum value of leaf $\Psi_{\mathrm{s}}$, in normal irrigation and during stressful conditions. However, the minimum $\Psi$ s was noted in plants without salicylic acid spray (No SA) and it was statistically at par with salicylic acid sprayed at vegetative plus reproductive growth stages of marigold plants. On imposing moisture stress, the leaf $\Psi_{\mathrm{s}}$ was minimum in plants without SA application. The results showed that both in regular irrigation and drought stress, SA@100 mg L $\mathrm{L}^{-1}$ application at reproductive stage of marigold plant had the greatest value of leaf turgor potential $(\Psi \mathrm{p})$. However, plants where salicylic acid was applied at vegetative plus reproductive stage, produced the minimum leaf $\Psi \mathrm{p}$ when water supply was normal. After drought stress application to plants, the minimum value of $\Psi \mathrm{p}$ was found in those plant which received salicylic acid foliar spray at vegetative plus reproductive stage in moisture stress conditions (Fig. 3).

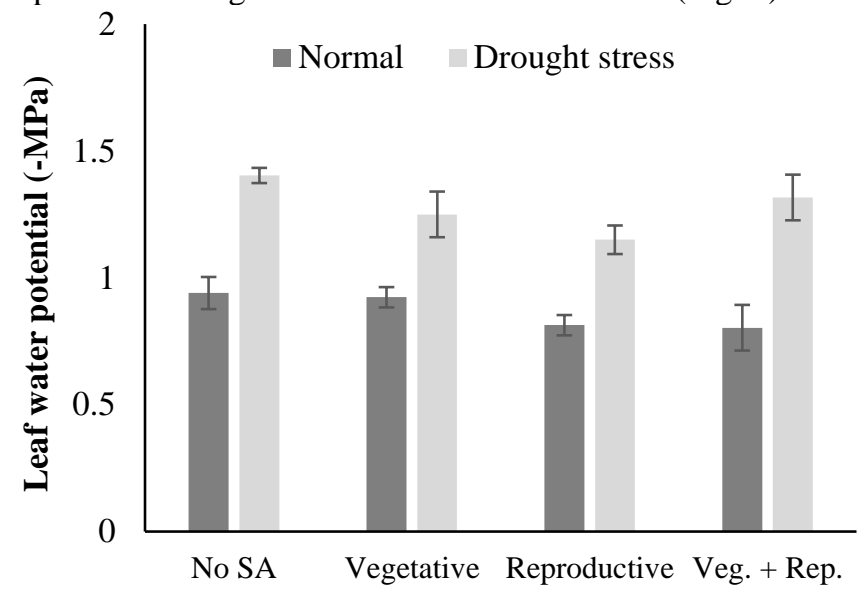

Figure 1. Effect of salicylic acid application on leaf water potential $(\Psi w)$ of marigold plants under normal and drought stress. Values are means \pm standard error.

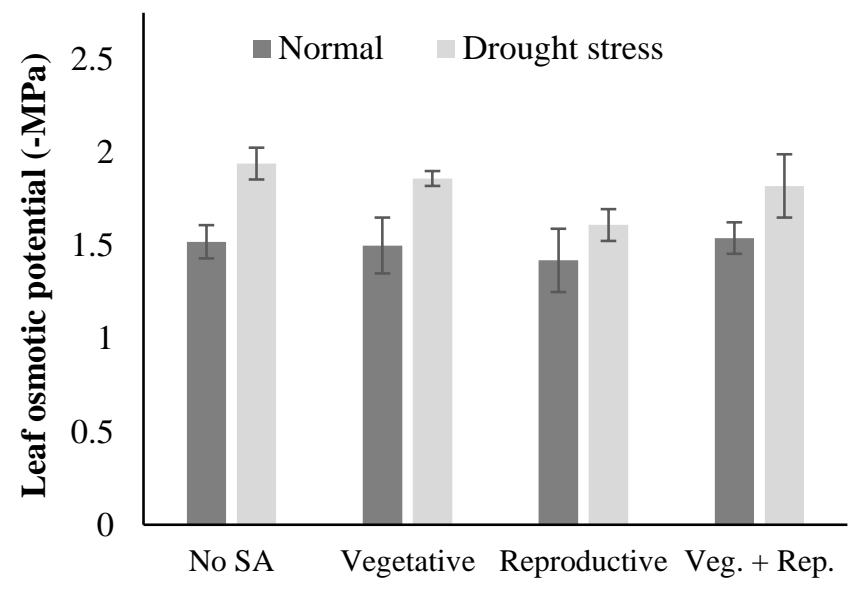

Figure 2. Effect of salicylic acid application $\left(100 \mathrm{mg} \mathrm{L}^{-1}\right)$ on leaf osmotic potential ( $\Psi$ s) of marigold (Tagetes erecta L.) plants under normal (no moisture stress) and drought stress (moisture stress) conditions. Values are means \pm standard error.

Table 1. Mean sum of squares of the data for leaf water potential (-MPa), leaf osmotic potential (-MPa), leaf turgor potential (MPa) and relative water contents (\%) of marigold (Tagetes erecta L.) under two drought stress levels in pots.

\begin{tabular}{lccccc}
\hline SOV $^{\mathbf{a}}$ & $\mathbf{D F}^{\mathbf{b}}$ & $\begin{array}{c}\text { Leaf water potential } \\
(-\mathbf{M P a})\end{array}$ & $\begin{array}{c}\text { Leaf osmotic } \\
\text { potential (-MPa) }\end{array}$ & $\begin{array}{c}\text { Leaf turgor } \\
\text { potential (MPa) }\end{array}$ & $\begin{array}{c}\text { Relative water } \\
\text { contents (\%) }\end{array}$ \\
\hline Stress & 1 & $1.04584^{* *}$ & $0.55510^{* *}$ & $0.07707^{* *}$ & $515.227^{* *}$ \\
SA & 3 & $0.03787^{* *}$ & $0.05494^{* *}$ & $0.01057^{* *}$ & $207.283^{* *}$ \\
Stress*SA & 3 & $0.01076^{* *}$ & $0.01540^{* *}$ & $0.01897^{* *}$ & $15.072^{\mathrm{ns}}$ \\
Error & 14 & 0.00058 & 0.00163 & 0.00145 & 19.019 \\
Total & 23 & & & & \\
\hline
\end{tabular}

$*=\mathrm{LSD} p \leq 0.05, * *=\mathrm{LSD} \mathrm{p} \leq 0.01,{ }^{\mathrm{ns}}=$ Non significant, ${ }^{\mathrm{a}} \mathrm{SOV}=$ Source of variation, ${ }^{\mathrm{b}} \mathrm{DF}=$ Degree of freedom, SA $=$ Salicylic acid 


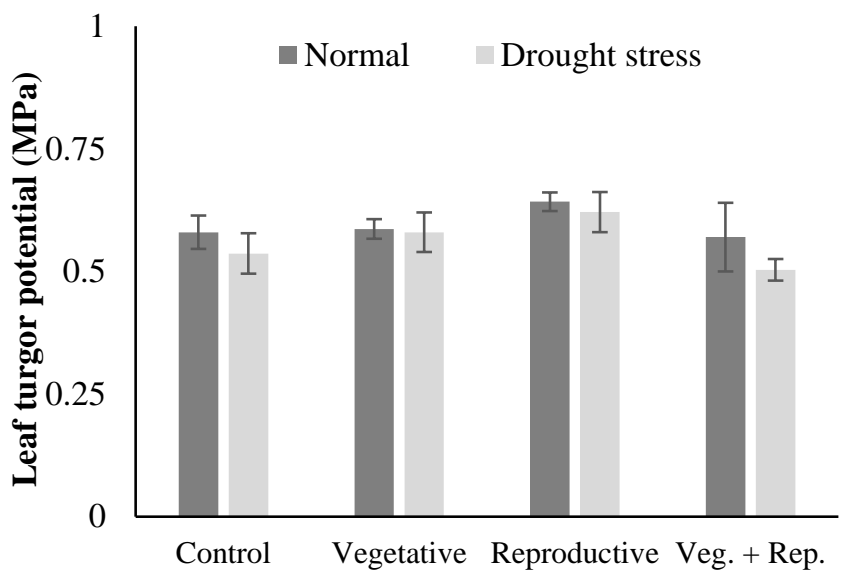

Figure 3. Effect of salicylic acid application $\left(100 \mathrm{mg} \mathrm{L}^{-1}\right)$ on leaf turgor potential ( $\Psi$ p) of marigold (Tagetes erecta L.) plants under normal (no moisture stress) and drought stress (moisture stress) conditions. Values are means \pm standard error.

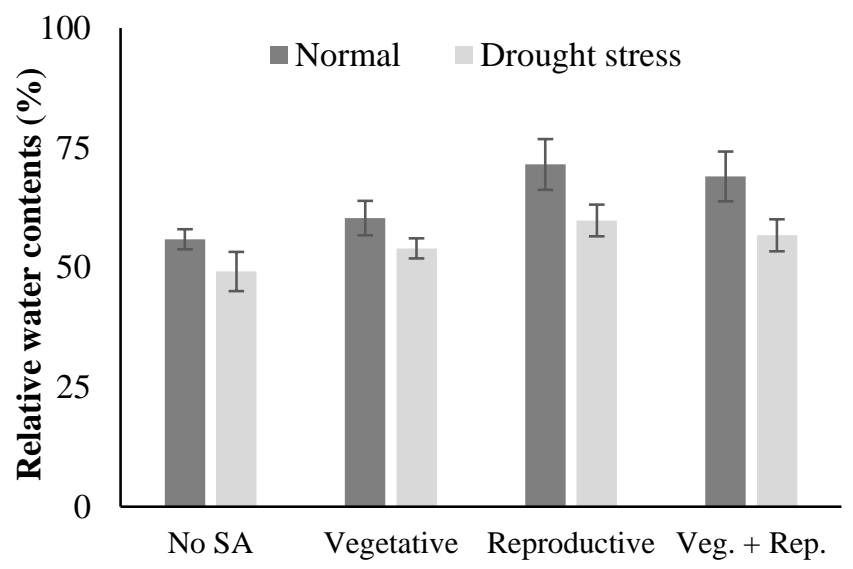

Figure 4. Effect of salicylic acid application (@ 100 $\mathrm{mg} \mathrm{L}^{-1}$ ) on relative water contents $(\%)$ of marigold (Tagetes erecta L.) plants under normal (no moisture stress) and drought stress (moisture stress) conditions. Values are means \pm standard error.
Relative water contents (RWC) were significantly decreased when moisture stress was imposed to plants (Table 1; Fig. 4). In plants grown under normal irrigation, RWC increased when foliar application of SA @ $100 \mathrm{mg} \mathrm{L}^{-1}$ was done at reproductive growth stage of marigold. While, the value of RWC was found minimum when no SA spray was applied in normal water supply. Whereas, the application of drought stress resulted in increase in RWC when SA was sprayed at reproductive growth stage of marigold. Absence of SA foliar application (No SA) caused reduction in RWC of marigold plants maintaining the least value for this variable under water stress environment.

The photosynthetic rate $(P n)$ of marigold plants decreased on reducing water supply. There were a significant variations in $P n$ of plants grown in normal moisture and in drought stress (Table 2). Photosynthetic rate was found the highest on applying SA @ $100 \mathrm{mg} \mathrm{L}^{-1}$ to marigold plants at reproductive growth stage under normal water supply as well as during drought stress conditions. Similarly, the plant grown without SA spray, exhibited the lowest values for photosynthetic rate, when grown with or without drought stress (Fig. 5). The transpiration rate $(E)$ of marigold plants was significantly $\mathrm{p}<$ 0.05 decreased due to drought stress imposition (Table 2; Fig. 6). Higher transpiration rate was maintained by marigold plants when SA@100 mg L ${ }^{-1}$ was applied at reproductive growth stage. However, the lowest transpiration rate was recorded in plant grown without SA treatment in normal and water stress conditions (Fig. 6). The stomatal conductance $(g s)$ was significantly influenced by drought stress (Table 2). The highest stomatal conductance was recorded when plants were sprayed with $100 \mathrm{mg} \mathrm{L}^{-1} \mathrm{SA}$ at reproductive growth stage of marigold under normal or drought conditions. While, the minimum values for stomatal conductance were noted in treatment without salicylic acid application during drought stress (Fig. 7). The results of sub-stomatal conductance $\mathrm{CO}_{2}$ rate was significantly reduced due to moisture stress (Table 2; Fig. 8). Marigold plants maintained better sub-stomatal $\mathrm{CO}_{2}$ rate on applying SA @ $100 \mathrm{mg} \mathrm{L}^{-1}$ at reproductive stage when they received normal watering as well as during water deficit.

Table 2. Mean sum of squares of data for photosynthetic rate (A) ( $\mu \mathrm{mol} \mathrm{CO} 2 \mathrm{~m}-1 \mathrm{~s}-1)$, transpiration rate (E) (mmol $\left.\mathrm{H}_{2} \mathrm{O} \mathrm{m}^{-1} \mathrm{~s}^{-1}\right)$, stomatal conductance $(\mathrm{gs})\left(\mathrm{mmol} \mathrm{H}_{2} \mathrm{O} \mathrm{m}^{-1} \mathrm{~s}^{-1}\right)$, sub-stomatal $\mathrm{CO}_{2}$ rate $(\mathrm{Ci})\left(\mu \mathrm{mol} \mathrm{CO}_{2} \mathrm{~mol}^{-1}\right)$ and dry weight of marigold (Tagetes erecta $L$.) plants under two drought stress levels in pots.

\begin{tabular}{|c|c|c|c|c|c|c|}
\hline aSOV & ${ }^{\mathrm{b} D F}$ & $\begin{array}{c}\text { Photosynthetic } \\
\text { rate }(A)(\mu \mathrm{mol} \\
\left.\mathrm{CO}_{2} \mathrm{~m}^{-2} \mathrm{~s}^{-1}\right)\end{array}$ & $\begin{array}{l}\text { Transpiration rate }(E) \\
\left(\mathbf{m m o l ~ H}_{2} \mathbf{O} \mathbf{~ m}^{-2} \mathbf{s}^{-1}\right)\end{array}$ & $\begin{array}{c}\text { Stomatal } \\
\text { conductance }\left(g_{s}\right) \\
\left(\mathbf{m m o l} \mathbf{H}_{2} \mathrm{O} \mathbf{~ m}^{-1} \mathbf{s}^{-1}\right)\end{array}$ & 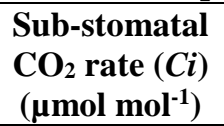 & $\begin{array}{l}\text { Dry weight } \\
\text { plant }^{-1}(g)\end{array}$ \\
\hline Stress & 1 & $522.014 * *$ & $632.427 * *$ & $0.66667 * *$ & $1338.62 * *$ & $2181.23^{* *}$ \\
\hline SA & 3 & $47.135^{* *}$ & 93.914** & $0.07326^{*}$ & $97.12^{\text {ns }}$ & $288.15^{* *}$ \\
\hline Stress*SA & 3 & $6.615^{* *}$ & $6.039 * *$ & $0.00421^{\mathrm{ns}}$ & $4.14^{\mathrm{ns}}$ & $52.93 * *$ \\
\hline Error & 14 & 0.680 & 0.353 & 0.02003 & 30.18 & 5.74 \\
\hline Total & 23 & & & & & \\
\hline
\end{tabular}




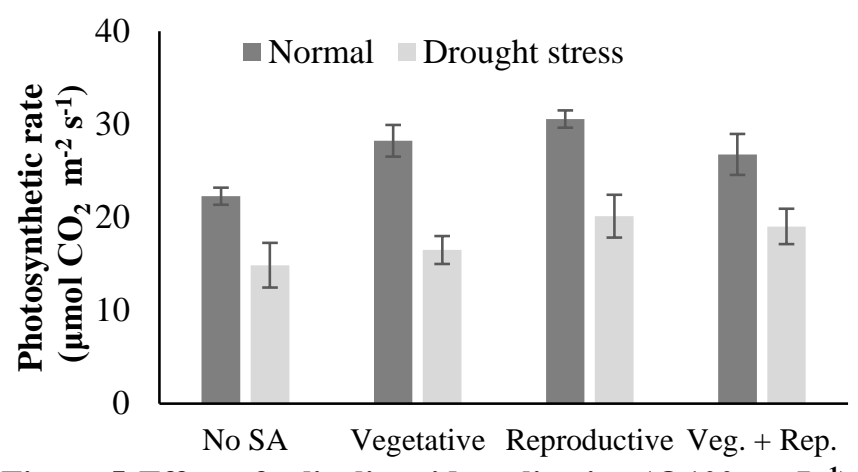

Figure 5. Effect of salicylic acid application (@100 $\mathrm{mg} \mathrm{L}^{-1}$ ) on photosynthetic rate $(A)\left(\mu \mathrm{mol} \mathrm{CO}_{2} \mathrm{~m}^{-1} \mathrm{~s}^{-1}\right)$ of marigold (Tagetes erecta L.) plants under normal (no moisture stress) and drought stress (moisture stress) conditions. Values are means \pm standard error.

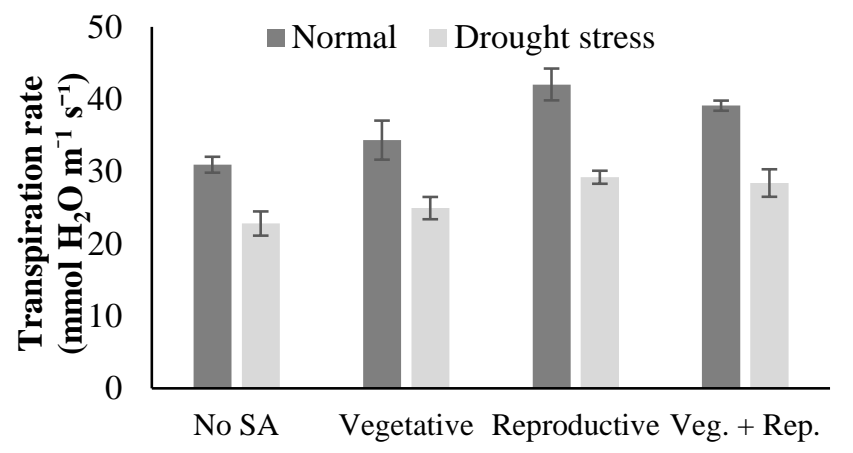

Figure 6. Effect of salicylic acid application (@ $100 \mathrm{mg} \mathrm{L}$ $\left.{ }^{1}\right)$ on transpiration rate $(E)\left(\mathrm{mmolH}_{2} \mathrm{O} \mathrm{m}^{-1} \mathrm{~s}^{-1}\right)$ of marigold (Tagetes erecta L.) plants under normal (no moisture stress) and drought stress (moisture stress) conditions. Values are means \pm standard error.

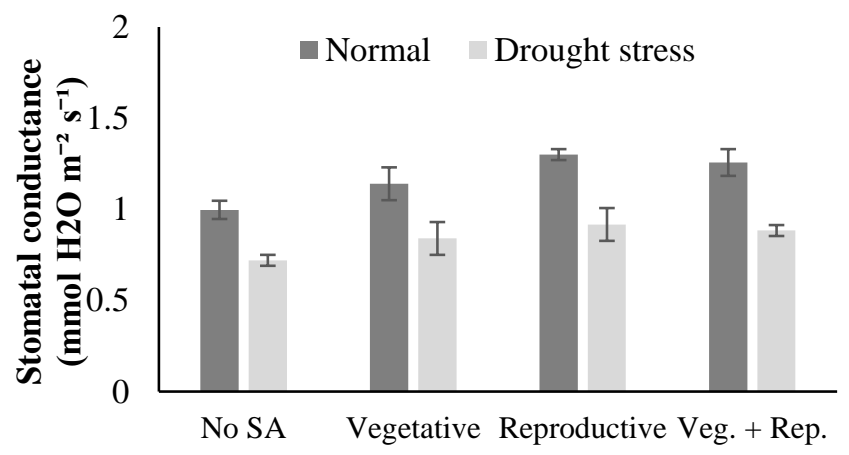

Figure 7.Effect of salicylic acid application (@100 $\mathrm{mg} \mathrm{L}^{-1}$ ) on stomatal conductance $\left(g_{s}\right)\left(\mathrm{mmol} \mathrm{H}_{2} \mathrm{O} \mathrm{m}^{-1} \mathrm{~s}^{-1}\right)$ of marigold (Tagetes erecta $\mathbf{L}$.) plants under normal (no moisture stress) and drought stress (moisture stress) conditions. Values are means \pm standard error.

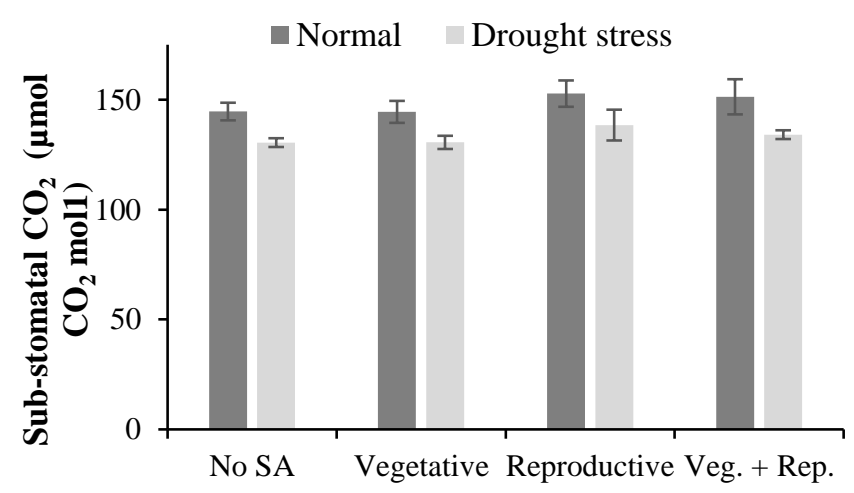

Figure 8. Effect of salicylic acid application $\left(100 \mathrm{mg} \mathrm{L}^{-1}\right)$ on sub-stomatal $\mathrm{CO}_{2}$ rate $(\mathrm{Ci})\left(\mu \mathrm{mol} \mathrm{CO} \mathrm{Cmol}^{-1}\right)$ of marigold (Tagetes erecta L.) plants under normal (no moisture stress) and drought stress (moisture stress) conditions. Values are means \pm standard error.

The lowest values of sub-stomatal $\mathrm{CO}_{2}$ rate were at par when SA was not applied (No SA) and when it sprayed at vegetative growth stage of marigold in normal and limited moisture supply (Fig. 8). The results of dry weight plant ${ }^{-1}$ of marigold are presented in Fig. 9. It is obvious from the data that the dry weight plant ${ }^{-1}$ of marigold was influenced significantly by drought stress (Table 2). During both normal moisture supply and drought stress, the maximum dry weight per plant was obtained by SA @ $100 \mathrm{mg} \mathrm{L}^{-1}$ foliar spray at reproductive growth stage of marigold plants. Minimum dry weight was recorded in marigold plants which were not treated with SA (No SA). The amount of plant dry weight was lowest with no salicylic acid application in water deficit condition and it was statistically increased with salicylic application at vegetative growth stage (Fig. 9).

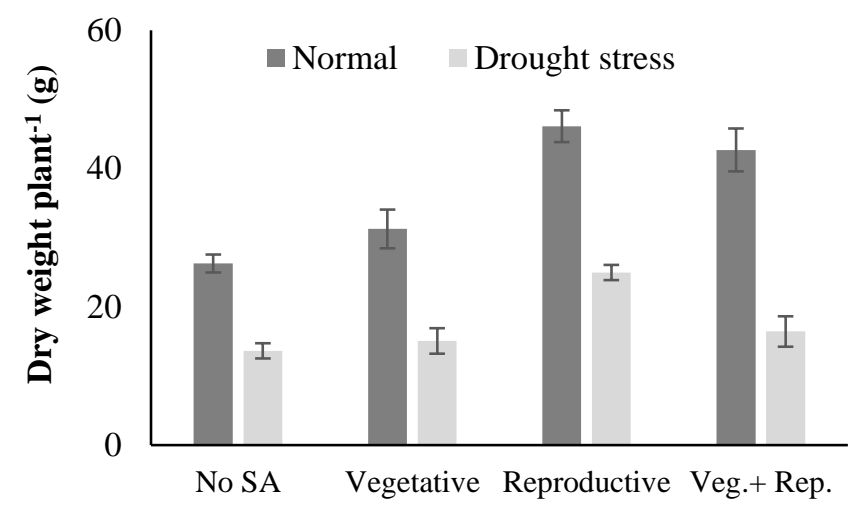

Figure 9. Effect of salicylic acid application (100 mg L-1) on dry weight plant $^{-1}(\mathrm{~g})$ of marigold (Tagetes erecta L.) under normal (no moisture stress) and drought stress (moisture stress) conditions. Values are means \pm standard error. 


\section{DISCUSSION}

Plant water relation were improved by $100 \mathrm{mg} \mathrm{L}^{-1}$ salicylic acid (SA) application at reproductive growth stage of marigold with or without imposing drought stress which is obvious from Figures 1 to 4 . Similar observations were recorded by other scientists (Hayat et al., 2008; Hashmi et al., 2012) who found an improvement in the leaf water potential and relative water contents by SA foliar application to drought affected tomato. Water potential in leaves of wheat also increased by salicylic acid spray under drought stress (Singh and Usha, 2003; Dalmia and Sawhney, 2004). Application of SA@100 $\mathrm{mgL}^{-1}$ in rice plants, grown under drought stress environment, significantly decreased leaf osmotic potential $(\Psi \mathrm{s})$, turgor potential $(\Psi \mathrm{p})$, leaf water potential $\left(\Psi_{\mathrm{w}}\right)$ and photosynthetic rate $(P n)$. There was a correlation between RWC, leaf proline and SA found under limited water supply (Farooq et al., 2009). Similarly, on applying foliar spray of SA under drought stress increased RWC and other water relations were also pointed out by Hayat et al. (2010).Same trend was witnessed in wheat by Singh and Usha (2003) and in Ctenanthe setosa by Kadioglu et al. (2011). Figs. 1 to 4 show that by SA treatment caused a manipulation of $\Psi_{s}$ and $\Psi$ p of plants which might be due to the process of osmotic adjustment, enhanced by SA application during deficit moisture environment. This phenomenon was also seen by others scientists (Machado and Paulsen, 2001; Hura et al., 2007). Transpiration causes more loss of water than the amount of water absorbed through roots. It was observed in earlier studies that SA treatment increased moisture absorption by plant roots and the amount of water loss by stomata was manipulated to decrease adverse effects of drought and it helped to regulate the availability of moisture in plants body (Makoto et al., 1990; Tas and Tas, 2007; Keyvan, 2010). The possible reasoning of our result are better explained by Sakhabutdinova et al. (2003) and He et al. (2005) who recorded that more production of photosynthates and sap in leaves caused an increase in RWC of plants when SA was foliar applied. Agarwal et al. (2005) described another reason of this process and explained that increase in amount of water contents of plants by SA foliar spray, in limited moisture availability, might be the result of less electrolyte leakage due to stabilization of membranes in plants. The data presented in Figures 5 to 8 show results of gas exchange parameters. Figure 5 depicts that photosynthetic rate was decreased on imposing drought stress to marigold plants. The possible reasons of decreased photosynthetic rate could be closure of stomata which reduces the supply and internal concentration of $\mathrm{CO}_{2}$ (Tiwari et al., 2005) inhibited rubisco activity (Yardanov et al., 2003) as well as other enzymes involved in photosynthesis (Lawlor, 2002; Reddy et al., 2005). Less stomatal conductance is the reason of reduction in photosynthesis (Farooq et al., 2008) and chlorophyll contents (Loggini et al., 1999). Whereas, SA improved photosynthetic activity which was also found in tomato grown under moisture stress where photosynthetic rate along with chlorophyll contents were increased by salicylic acid application (Fariddudin et al., 2003; Hayat et al., 2008). By application of $\mathrm{SA}$, transpiration rate and stomatal conductance were enhanced which might be another reason for increased photosynthetic rate in plants (Khan et al., 2003). Salicylic acid treatment improved stomatal conductance, transpiration and sub-stomatal $\mathrm{CO}_{2}$ in marigold plants as shown in Figures 6 to 8. Khan et al. (2003) and Nazar et al. (2015) explained that SA spray improved stomatal conductance, rate of transpiration and sub-stomatal $\mathrm{CO}_{2}$ rate which might be one reason of more photosynthetic rate. The results obtained by salicylic acid spray in okra plants during drought stress, showed more germination as a result of increased rate of stomatal conductance (Baghizadeh and Hajmohammadrezae, 2011). Noreen and Ashraf (2008) had similar observations regarding this phenomenon. Nazar et al. (2015) found better photosynthesis and plant growth by salicylic acid application. They explained its important role to regulate plant responses during moisture stress and suggested its use as potential growth regulator to improve plant drought tolerance. Under drought stress, there was a harmful impact on dry and fresh plant weights of marigold. However, salicylic acid foliar treatment at reproductive growth stage of marigold regained more plant dry weight (Fig. 9). Same results were also reported by different researchers in other crops (Fitter and Hay, 2002; Hamayun et al., 2010). Farooq et al. (2009) observed a decline in dry and fresh plant weight in rice during drought and $\mathrm{SA}$ application at reproductive growth stage with $100 \mathrm{mg} \mathrm{L}^{-1}$ repaired this loss. They further explain that decrease in plant fresh and dry weights during drought stress might be an indication of damage to photosynthesis process caused by unavailability of adequate moisture during drought stress conditions. Salicylic acid foliar application increase in dry matter of wheat in limited water availability (Singh and Usha, 2003).

Conclusions: It is concluded that marigold plant is badly affected by drought stress if it is not managed timely. Foliar application of $100 \mathrm{mg} \mathrm{L}^{-1}$ salicylic acid at reproductive growth stage was the best dose and time to improve various physiological parameters resulting in increased plant growth and productivity.

\section{REFERENCES}

Agarwal, S., R.K. Sairam, G.C. Srivastava and R.C. Meena. 2005. Changes in antioxidant enzymes activity and oxidative stress by abscisic acid and salicylic acid in Wheat genotypes. Biol. Plant. 49:541-550.

Akhtar, I. and N. Nazir. 2013. Effect of waterlogging and drought on plants. Intl. J. Water Res. Envir. Sci. 2:34-40. 
Arora, A., R. Sairam and G. Srivastava. 2002. Oxidative stress and antioxidative system in plants. Curr. Sci. Bangalore 82:1227-1238.

Ashraf, M. 2010. Inducing drought tolerance in plants. J. Biotechnol. Adv. 28:169-183.

Baghizadeh, A. and M. Hajmohammadrezaei. 2011. Effect of drought stress and its interaction with ascorbate and salicylic acid on Okra (Hibiscus esculentus L.) germination and seedling growth. J. Stress Phy. Biochem. 7:55-65.

Balbaa, L.K., G.A.E.A. Nehd and A.A. Yousef. 2008. Physiological effects of stigmasterol and nicotimanide on growth, flowering, oil yield and some chemical composition of Tagetes erecta L. Plant J. Appl. Sci. Res. 3:1936-1942.

Burnett, S.E., M.W.V. Iersel and A.P. Thomas. 2006. Medium-incorporated PEG-8000 reduces elongation, growth and whole-canopy carbondioxide exchange of Marigold. HortScience 41:124-130.

Chyliński, K.W. and A. Łukaszewska. 2008. Reaction of bedding ornamentals to drought stress. In: A. Lisowski, A. Ekielski and M. Gaworski (eds.), Annuals of Warsaw University of Life Sciences - SGGW. Horticulture and Landscape Architecture. pp.39-44.

Cornic, G. 1994. Drought stress and high light effects on leaf photosynthesis. In: N.R. Baker, J.R. Boyer, (eds.), Photoinhibition of photosynthesis: from molecular mechanisms to the field. Bios Scientific Publishers, Oxford; pp.297-313.

Dalmia, A. and V. Sawhney. 2004. Antioxidant defense mechanism under drought stress in wheat seedlings. Physiol. Mol. Biol. Plants 10:109-114.

Deineka, R., M.Y. Tret'yakov, S.M. Lapshova and L.A. Deineka. 2014. Thiophenes of Tagetes flowers and partial purification of xanthophyll esters. Univ. J. Agr. Res. 2:101-106.

Devika, R. and Y.J. Koilpillai. 2014. Physicochemical screening of Tagetes erecta Linn. Proc. World Cong. Engg. 1:196-209.

Farooq, M., A. Wahid, N. Kobayashi, D. Fujita and S. Basra. 2009. Plant drought stress: effects, mechanisms and management. Agron. Sustain. Dev. 29:185-212.

Farooq, M., S.M.A. Basra, A. Wahid, Z.A. Cheema, M.A. Cheema, and A. Khaliq. 2008. Physiological role of exogenously applied glycinebetaine in improving drought tolerance of fine grain aromatic Rice (Oryza sativa L.). J. Agron. Crop Sci. 194:325-333.

Fitter, A.H. and R.K.M. Hay. 2002. Environmental physiology of plants. Academic Press, San Francisco, California.

Hashmi, N., M.M.A. Khan, M.M. Idrees and T. Aftab. 2012. Exogenous salicylic acid stimulates physiological and biochemical changes to improve growth, yield and active constituents of Fennel essential oil. J. Plant Grth. Reg. 68:281-291.

Hamayun, M., E.Y. Sohn, S.A. Khan, Z.K. Shinwari, A.L. Khan and I.J. Lee. 2010. Silicon alleviates the adverse effects of salinity and drought stress on growth and endogenous plant growth hormones of Soybean (Glycine $\max$ L.). Pak. J. Bot. 42:1713-1722.

Hayat, Q., S. Hayat, M. Irfan and A. Ahmad. 2010. Effect of exogenous salicylic acid under changing environment: A review. Environ. Exper. Bot. 68:14-25.

Hayat, S., S.A. Hasan, Q. Fariduddin and A. Ahmad. 2008. Growth of Tomato (Lycopersicon esculentum L.) in response to salicylic acid under water stress. J. Plant Inter. 3:287-301.

He, Y., Y. Liu, W. Cao, M. Huai, B. Xu. and B. Huang. 2005. Effects of salicylic acid on heat tolerance associated with antioxidant metabolism in kentucky bluegrass. Crop Sci. 45:988-995.

Hoagland, D.R. and D.I. Arnon. 1950. The water-culture method for growing plants without soil. Circular California Agri. Exper. Station. $2^{\text {nd }}$ Ed., pp.347:34.

Hura, T., K. Hura, M. Grzesiak and A. Rzepka. 2007. Effect of long-term drought stress on leaf gas exchange and fluorescence parameters in $\mathrm{C}_{3}$ and $\mathrm{C}_{4}$ plants. Acta Physiol. Plant. 29:103-113.

Jamil, M., M. Ahamd, F. Anwar, Z.A. Zahir, M.A. Kharal and F. Nazli. 2018. Inducing drought tolerance in wheat through combined use of L-tryptophan and Pseudomonas fluorescens. Pak. J. Agri. Sci. 55:331-337.

Jiang, M. and J. Zhang. 2001. Effects of abscisic acid on active oxygen species, antioxidative defense system and oxidative damage in leaves of Maize seedlings. Plant Cell Physiol. 42:1265-1273.

Kadioglu, A., N. Saruthan, A. Saglam, R. Terzi and T. Acet. 2011. Exogenous salicylic acid alleviates effects of long term drought stress and delays leaf rolling by increasing antioxidant system. Plant Growth Regul. 64:27-37.

Keyvan, S. 2010. The effect of drought stress on yield, relative water content, proline, soluble carbohydrates and chlorophyll of bread Wheat cultivars. J. Anim. Plant Sci. 8:1051-1060.

Khan, W., B. Prithiviraj and D. Smith. 2003. Photosynthetic response of corn and soybean to foliar application of salicylates. J. Plant Physiol. 160:485-492.

Khulbe, A. 2015. A review on Tagetes erecta L. World J. Pharm. Sci. 3:645-649.

Lawlor, D.W. 2002. Limitation to photosynthesis in waterstressed leaves: Stomatal metabolism and the role of ATP. Ann. Bot. 89:871-885.

Loggini, B., A. Scartazza, E. Brugnoli, and F. Navari-Izzo. 1999: Antioxidative defense system, pigment composition, and photosynthetic efficiency in two wheat cultivars subjected to drought. Plant Physiol. 119:10911100 . 
Machado, S. and G.M. Paulsen. 2001. Combined effects of drought and high temperature on water relations of wheat and sorghum. Plant Soil 233:179-187.

Makoto, T.B., B.F. Carver, R.C. Johnson and E.L. Smith. 1990. Relationship between water content and grain yield during reproductive period in winter wheat. Euphytica 49:255-262.

Mastalerczuk, G., B. Borawska-Jarmułowicz and H. M. Kalaji. 2017. Response of Kentucky bluegrass lawn plants to drought stress at early growth stages. Pak. J. Agri. Sci.54:791-797.

Mavi, K. 2014. Use of extract from dry marigold (Tagetes spp.) flowers to prime eggplant (Solanum melongena L.) seeds. Acta Sci. Pol., Hort. Cultus. 13:3-12.

Miura, K. and Y. Tada. 2014. Regulation of water, salinity, and cold stress responses by salicylic acid. Plant Physiol. 5:1-12.

Monakhova, O. and I. Chernyadev. 2002. Protective role of kartolin-4 in wheat plants exposed to soil drought. Appl. Biochem. Microbiol. 38:373-380.

Moussa, H.R. 2006. Influence of exogenous application of silicon on physiological response of salt-stressed maize (Zea mays L.). Int. J. Agric. Biol. 8:293-297.

Munhoza, V.M., R. Longhinia, J.R.P. Souzab, J.A.C. Zequic, E.V.S.L. Mellod, G.C. Lopesa and J.C.P. Melloa. 2014. Extraction of flavonoids from Tagetes Patula L: Process optimization and screening for biological activity. Rev. Bras. Farmacogn. 24:576-583.

Nazar, R., S. Umar, N.A. Khan and O. Sareera. 2015. Salicylic acid supplementation improves photosynthesis and growth in mustard through changes in proline accumulation and ethylene formation under drought stress. S. Afri. J. Bot. 98:84-94.
Noreen, S. and M. Ashraf. 2008. Alleviation of adverse effects of sunflower (Helianthus annus L.) by exogenous application of salicylic acid growth and photosynthesis. Pak. J. Bot. 40:1657-1663.

Reddy, A.R., K.V. Chaitanya, P.P. Jutur and A. Granam. 2005. Photosynthesis and oxidative stress responses to water deficit in five different mulberry (Morus alba L.) cultivars. Physiol. Mol. Biol. Plants 11:291-298.

Sakhabutdinova, A.R., D.R. Fatkhutdinova, M.V. Bezrukova and F.M. Shakirova. 2003. Salicylic acid prevents the damaging action of stress factors on wheat plants. J. Plant Physiol. 314-319.

Singh, B. and K. Usha. 2003. Salicylic acid induced physiological and biochemical changes in wheat seedlings under water stres. Plant Growth Regul. 39:137141.

Steel, R.G.D., J.H. Torrie and D. Dickey. 1997. Principles and Procedures of Statistics: A biometrical approach, $3^{\text {rd }} \mathrm{Ed}$. McGraw Hill Book Co. Inc. New York, USA; pp.172177.

Tas, S. and B. Tas. 2007. Some physiological responses of drought stress in wheat genotypes with different ploidity in Turkiye. World J. Agri. Sci. 3:178-183.

Tiwari, A., P. Kumar, S. Singh and A.S. Ansari. 2005. Carbonic anhydrase in relation to higher plants. Photosynthetica 43:1-11.

Yardanov, I., V. Velikova and T. Tsonev. 2003. Plant responses to drought and stress tolerance. Bull. J. Plant Physiol. :187-206.

Zhang, Y.G., Q.H. Wang, X. Zhang, X.L. Liu, P. Wang and Y.X. Hou. 2011. Cloning and characterization of an annexin gene from Cynanchum komarovii that enhances tolerance to drought and Fusarium oxysporum in transgenic cotton. J. Plant Biol. 54:303-313. 